\title{
STUDI PENGARUH ALIRAN KONVEKSI PADA PERBEDAAN LETAK SUBSTRAT PROSES SINTESIS STRUKTUR KRISTAL ZNO NANOROD
}

\author{
Anisah Fauziyyah $^{1, a)}$, Isnaeni ${ }^{2, a)}$, Iwan Sugihartono ${ }^{1, a)}$ \\ ${ }^{1}$ Program Studi Fisika, FMIPA Universitas Negeri Jakarta, Jl. Rawamangun Muka No. O1, Rawamangun \\ 13220, Indonesia \\ ${ }^{2}$ Research Center for Physics, Indonesian Institute of Sciences, Banten 15314, \\ Indonesia \\ Email: a)fauziyyah.anisah@gmail.com
}

\begin{abstract}
Abstrak
Berdasarkan hasil review, $\mathrm{ZnO}$ nanorod dapat ditumbuhkan diatas substrat silicon (Si) pada suhu $90{ }^{\circ} \mathrm{C}$ dengan Teknik Hidrotermal selama 2 jam. Pengamatan dilakukan untuk melihat pengaruh aliran konveksi pada peletakan substrat di dalam botol selama proses sintesis terhadap struktur kristal nanorod $\mathrm{ZnO}$. Scanning Electron Microscopy (SEM) akan dilakukan untuk menguji morfologi sampel nanorod $\mathrm{ZnO}$. Teknik difraksi sinar-x (XRD) akan dilakukan untuk menguji struktur kristal nanorod ZnO pada suhu ruang. Spektrum XRD yang diperoleh akan dikonfirmasi menggunakan standar yang mengacu pada Inorganic Crystal Structure Database (ICSD). Perhitungan Full Width at Half Maximum (FWHM), ukuran kristalit, dan strain akan dilakukan sesuai persamaan Debye-Scherer. Selanjutnya penelitian ini diharapkan dapat berupa analisis pada sampel nanorod $\mathrm{ZnO}$ di atas substrat $\mathrm{Si}$ yang disintesis dengan posisi letak berbeda.
\end{abstract}

Kata Kunci: Nanorod ZnO, Konveksi, Posisi, SEM, XRD

\begin{abstract}
Based on paper review, $\mathrm{ZnO}$ nanorod can be grown on silicon substrate ( $\mathrm{Si}$ ) by hydrothermal at 90 oC for 2 hours. Observations were made to see the effect of convection flow on the placement of the substrate in the bottle during the synthesis process of the $\mathrm{ZnO}$ nanorod crystal structure. Scanning Electron Microscopy (SEM) will be conducted to answer the morphology of ZnO nanorod samples. Xray diffraction (XRD) techniques will be carried out to provide the crystal structure of $\mathrm{ZnO}$ nanorods at room temperature. The XRD spectrum obtained will use the standard requested in the Inorganic Crystal Structure Database (ICSD). Calculations of Full Width at Half Maximum (FWHM), crystallite size, and strain will be performed according to Debye-Scherer. Furthermore, this research can be carried out sample analysis on $\mathrm{ZnO}$ nanorods on $\mathrm{Si}$ substrate synthesized with different position.
\end{abstract}

Keywords: ZnO Nanorod, Convection, Position, SEM, XRD 


\section{PENDAHULUAN}

Sebuah inovasi-inovasi yang muncul saat ini terutama dalam perkembangan teknologi seolah mengikuti tren seperti mengarah pada ukuran partikel-partikel penyusun yang semakin kecil terutama dibidang nanomaterial. Berdasarkan dari jumlah dimensi dalam rentang nanometer, nanomaterial diklasifikasikan menjadi beberapa macam dan di antaranya struktur satu dimensi (1D) nano seperti nanorod telah menarik banyak perhatian semenjak dekade terakhir ini karena sifatnya yang unik yang membuatnya menjadi kandidat yang cocok untuk perangkat optoelektronik dalam skala nano, terutama perangkat pemancar cahaya [1]. Pada beberapa penelitian material semikonduktor yang banyak digunakan didalam pembentukan nanorod ialah Zinc Oxide $(\mathrm{ZnO})$. $\mathrm{ZnO}$ memiliki lebar celah pita semikonduktor sebesar 3,37 eV pada suhu kamar, energi ikat eksiton sebesar $60 \mathrm{MeV}$, dan merupakan material luminisens [2].

Dalam pembentukan $\mathrm{ZnO}$ nanorod ini terdapat beberapa metode yang digunakan namun dalam hal ini menggunakan metode sintesis hidrotermal yang mempunyai beberapa kelebihan seperti ramah lingkungan, menggunakan peralatan sintesis murah dan mudah, serta waktu reaksi cepat dan dapat menggunakan temperatur yang rendah [3]. Metode hidrotermal ialah metode yang menggunakan air dan panas yang sifatnya mengubah larutan menjadi kristal [4]. Metode hidrotermal ini harus di proses dalam sistem tertutup untuk mencegah hilangnya pelarut saat dipanaskan diatas titik didihnya [5]. Oleh karena itu dapat mempengaruhi kristalinitas produk yang akan dihasilkan dari metode hidrotermal tersebut [6].

Dalam proses hidrotermal ini kalor berpindah dengan cara pergerakkan partikel yang telah dipanaskan dapat dikatakan perpindahan kalor secara konveksi. Maka dari itu sebuah aliran konveksi yang mengalir pada proses hidrotermal akan berhubungan dengan struktur kristal dan morfologi $\mathrm{ZnO}$ Nanorod. Selanjutnya pada paper ini bertujuan untuk mereview dari beberapa jurnal mengenai perbedaan pengaruh aliran konveksi pada posisi peletakan substrat yang berbeda yaitu secara horizontal dan vertikal terhadap morfologi sampel $\mathrm{ZnO}$ nanorod serta struktur kristal $\mathrm{ZnO}$ nanorod.

\section{METODOLOGI PENELITIAN}

Proses deposisi lapisan tipis $\mathrm{ZnO}$ Nanorod pada substrat telah berhasil dibuat dengan metode hidrotermal pada beberapa penelitian dan akan direview pada jurnal ini dibandingkan semua hasilnya. Selanjutnya alat yang digunakan dalam penelitian ini adalah Utrasonic cleaner, furnace, timbangan digital, gelas beaker, botol duran. Selain itu bahan yang digunakan antara lain substrat kaca Si, Zinc Acetate Dihydrat (ZAD), Zinc Nitrate Tetrahydrat (ZNT), Hexamethylenetetramine (HMT), Isopropanol, dan DI water.

Sintesis $\mathrm{ZnO}$ nanorods diawali dengan memotong substrat $\mathrm{Si}$ serta dimasukkan kedalam gelas beaker didalam ultrasonic cleaner dengan DI water dan isopropanol selama 15 menit. Kemudian pembuatan lapisan benih $\mathrm{ZnO}$ dengan prekursor Zinc Acetate Dihydrat (ZAD) yang dilarutkan dengan DI water yang disintesis dengan metode Ultrasonic Spray Pyrolysis (USP). Larutan ZNT dan HMT dibuat dengan perbandingan molar yang sama yaitu 0,1 M dan dilarutkan dengan DI water. Kedua larutan yang dicampur dan diaduk hingga homogen dengan ultrasonic cleaner. Substrat yang telah dilapisi seed layer, kemudian dimasukkan ke dalam larutan dengan 2 variasi posisi yang berbeda yaitu dengan posisi substrat horizontal dan vertikal digantung. Setelah itu, dilakukan sintesis $\mathrm{ZnO}$ nanorods dengan metode hidrotermal pada temperatur $90^{\circ} \mathrm{C}$ selama 2 jam. Hasil struktur dan sifat absorbansi optik sampel telah dilakukan menggunakan pengukuran Scanning Electron Microscope (SEM), X-Ray Difraction (XRD). 


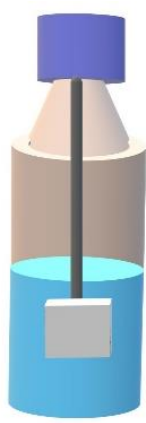

(a)

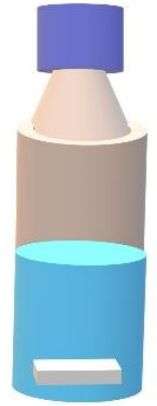

(b)

GAMBAR 1. (a) Peletakan substrat secara vertikal, (b) Peletakan substrat secara horizontal

\section{HASIL DAN PEMBAHASAN}

Dalam artikel ini, akan dilakukan review beberapa hasil penelitian untuk membuat hipotesis hasil penumbuhan $\mathrm{ZnO}$ nanorod dengan metode hidrotermal pda suhu 90 oC selama 2 jam. Pengamatan dilakukan pada 2 kondisi pelatakan substrat secara vertikal dan horizontal. Posisi substrat yang berbeda akan mempengaruhi proses pertumbuhan $\mathrm{ZnO}$ nanorod akibat pengaruh aliran konveksi. Ilustrasi dari kondisi tersebut dapat dilihat pada GAMBAR 2.

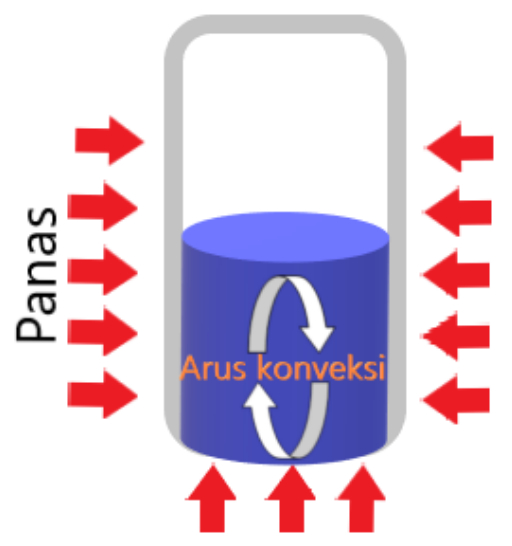

GAMBAR 2. Ilustrasi proses arus konveksi

Menurut Gu dkk, ZnO nanorod berdasarkan hasil pola difraksi sinar x (XRD) dengan larutan konsentrasi tinggi memiliki puncak pada bidang (002), dan orientasi yang lemah ditunjukkan pada konsentrasi larutan terendah selain itu sebagian besar $\mathrm{ZnO}$ Nanorod menunjukkan struktur heksagonal wurtzite. Diameter yang dihasilkan pada $\mathrm{ZnO}$ nanorod yang dilakukan $\mathrm{Gu}$ dkk adalah $0,51 \mu \mathrm{m}$ besar dari diamter dipengaruhi oleh konsentrasi prekursor. Selain itu, berdasrkan pengujian SEM terkonfirmasi bahwa konsentrasi prekursor mempengaruhi panjang $\mathrm{ZnO}$ nanorod. Adapun panjang rata-rata $\mathrm{ZnO}$ nanorod yang teramati adalah $6.17 \mu \mathrm{m}$ searah dengan sumbu-c [7].

Namun demikian yang dilaporakan oleh Babak dkk menunjukan hasil yang sedikit berbeda, yaitu meningkatnya kerapatan $\mathrm{ZnO}$ nanorod seiring dengan bertambahnya volume larutan berdasarkan pengujian SEM. Meskipun diameter batang tetap tidak berubah, dan panjangnya tumbuh hingga 1,5 $\mu \mathrm{m}$. Dengan pola XRD semua sampel menunjukkan struktur heksagonal wurtzite dengan puncak bidang (002) [8].

Berbeda pada penelitian Khamkhom dkk yang melakukan peletakan substrat secara horizontal. Dihasilkan pengujian SEM bahwa semakin lama proses penumbuhan $\mathrm{ZnO}$ nanorod menunjukkan peningkatan diameter yaitu $0,04 \mu \mathrm{m}$ dan panjangnya sekitar $0,3 \mu \mathrm{m}$ selama proses pemanasan 2 jam di suhu 90 oC. Pada pola XRD menunjukan semua sampel diidentifikasi sebagai polikristalin yang sesuai dengan struktur $\mathrm{ZnO}$ heksagonal wurtzite. Hasil menunjukkan bahwa dengan meningkatnya waktu pertumbuhan, ada peningkatan yang signifikan dalam intensitas puncak difraksi sesuai dengan bidang (002) karena orientasi $\mathrm{ZnO}$ nanorod horizontal [9]. 
Dari proses hidrotermal itu sendiri sangat mempengaruhi dalam hal peletakan sebuah substrat yang dimana terdapat sebuah aliran konveksi didalamnya saat proses peredaman larutan kimia dengan suhu tinggi. Dimana air dengan gaya gravitasi nya selalu mempunyai kecenderungan untuk bergerak ke bawah, akan tetapi apabila air tersebut kontak dengan suatu sumber panas maka akan terjadi perpindahan panas sehingga temperatur air menjadi lebih tinggi dan air menjadi lebih ringan sehingga berputar searah jarum jam alirannya.

Keadaan ini menyebabkan air yang lebih panas bergerak ke atas sedangkan air yang lebih dingin bergerak turun ke bawah dan terjadi sirkulasi air atau arus konveksi [10]. Pada saat proses perpindahan panas tersebut pindah keatas dan pergerakan partikel pun lebih banyak terjadi dibagian substrat yang posisinya vertikal atau menggantung. Berbeda dengan substrat yang letaknya horizontal atau mengendap dibawah akibatknya tidak banyak bertemu partikel yang bergerak dari arus konveksi tersebut.

\section{PENUTUP}

Proses hidrotermal ialah proses terbentuknya mineral yang terjadi oleh pengaruh temperatur dan tekanan yang sangat rendah. Dimana air dengan gaya gravitasi nya selalu mempunyai kecenderungan untuk bergerak ke bawah, akan tetapi apabila air tersebut kontak dengan suatu sumber panas maka akan terjadi perpindahan panas sehingga temperatur air menjadi lebih tinggi dan air menjadi lebih ringan. Keadaan ini menyebabkan air yang lebih panas bergerak ke atas sedangkan air yang lebih dingin bergerak turun ke bawah dan terjadi sirkulasi air atau arus konveksi. Dari hasil SEM dan XRD menggambarkan bahwa substrat dengan posisi vertikal memiliki stuktur morfologi yang lebih baik diantaranya memiliki panjang dan diameter yang lebih besar serta kepadatan yang lebih teratur pada temperatur 90 oC selama 2 jam.

\section{UCAPAN TERIMAKASIH}

Terimakasih kepada kedua orang tua telah membimbing hingga saat ini dan pihak beasiswa PPA (Peningkatan Prestasi Akaemik) tahun 2018-2019 yang telah memberikan bantuan biaya perkuliahan.

\section{REFERENSI}

[1] K. P. Singh, et al., "Synthesis of Zinc Nanoparticles By Wet Chemical Method and Study of Enhancement of the Antimicrobial Activity of Antibiotics By Zinc Nanoparticles," J. Nepal Assoc. Med. Lab. Sci, vol. 11, no. 1, pp. 54-58, 2012.

[2] A. Vanaja and K. S. Rao, "Effect of Co Doping on Structural and Optical Properties of Zinc Oxide Nanoparticles Synthesized by Sol-Gel Method," Adv. Nanoparticles, vol. 05, no. 01, pp. 83-89, 2016.

[3] M. Chakraborty, P. Mahapatra and R. Thangavel, "Structural, optical and electrochemical properties of $\mathrm{Al}$ and $\mathrm{Cu}$ co-doped $\mathrm{ZnO}$ nanorods synthesized by a hydrothermal method," Thin Solid Films, vol. 612, pp. 49-54, 2016.

[4] K. W. Jung, S. Y. Lee and Y. J. Lee, "Hydrothermal synthesis of hierarchically structured birnessite-type $\mathrm{MnO}$ /biochar composites for the adsorptive removal of $\mathrm{Cu}$ (II) from aqueous media," Bioresour, Technol, vol. 260, no. 2, pp. 204-212, 2018.

[5] G. T. Zhu, et al., "Hydrothermally tailor-made chitosan fiber for micro-solid phase extraction of petroleum acids in crude oils," J. Chromatogr A, vol. 1564, pp. 42-50, 2018.

[6] G. Gallina, et al., "Hydrothermal extraction of hemicellulose: from lab to pilot scale," Bioresour Technol, vol. 247, pp. 980-991, 2018.

[7] P. Gu, X. Zhu and D. Yang, "Vertically aligned $\mathrm{ZnO}$ nanorods arrays grown by chemical bath deposition for ultraviolet photodetectors with high response performance," J. Alloys Compd, vol. 815, p. 152346, 2020. 
[8] B. Efafi, et al., "Improvement in photoluminescence behavior of well-aligned $\mathrm{ZnO}$ nanorods by optimization of thermodynamic parameters," Phys. B Condens Matter, vol. 579, p. 411915, 2020.

[9] P. Khamkhom et al., "Hydrothermal synthesis of photo-induced hydrophilic $\mathrm{ZnO}$ nanorods," Mater Today Proc, vol. 5, no. 6, pp. 14121-14125, 2018.

[10] S. Inaba, "Primary Formation Path of Formaldehyde in Hydrothermal Vents," Orig. Life Evol. Biosph, vol. 48, no. 1, pp. 1-6, 2018. 
